\title{
The new relaxants: are they worth it?
}

David R. Bevan MB MRCP FRCA

M

$\mathrm{UCH}$ of the current neuromuscular drug development programs are concerned with the search for a replacement for the rapid onset, short duration succinylcholine. This has led to re-evaluation and re-definition of muscle relaxants by the FDA according to their onset and duration of action in a dose of $2 \times \mathrm{ED}_{95}$ (Table I). ${ }^{1}$ It is unlikely that any neuromuscular blocking drug will be introduced into clinical practice unless it is almost free of cardiovascular activity. The purpose of this presentation is to describe factors leading to the development of new drugs and to review the pharmacology of the recently introduced intermediate-acting neuromuscular blocking drugs rocuronium, mivacurium, cisatracurium and rapacuronium. One of the problems in the development of the "Ideal Relaxant" is cost. An attempt will be made to put the price of muscle relaxants into perspective.

\section{Onset of Action}

Onset depends on the arrival at the receptor of sufficient molecules either to produce depolarization of the endplate (depolarizing NMBDs) or to prevent acetylcholine from reaching enough receptors to cause neuromuscular transmission (non-depolarizing NMBDs). Speed of onset is affected mainly by the rate of delivery of the drug to the junction. It is modified by drug potency and its metabolism. The onset of non-depolarizing relaxants is inversely proportional to their potency. ${ }^{2}$ Thus, of the five recently introduced relaxants - doxacurium, mivacurium, pipecuronium, rocuronium, cisatracurium, the most potent, doxacurium $\left(\mathrm{ED}_{50} 0.015 \mathrm{mg} \cdot \mathrm{kg}^{-1}\right)$ has the slowest onset $(10-15 \mathrm{~min})$ and the least potent, roccuronium $\left(\mathrm{ED}_{50} 0.15 \mathrm{mg} \cdot \mathrm{kg}^{-1}\right)$, the most rapid $(1.5-2.5 \mathrm{~min})$ and seems to be nearly as rapid as succinylcholine ${ }^{3}$ (Table II). The quick onset of succinylcholine is related to its prompt metabolism and plasma clearance. When metabolism is impaired, i.e. in the presence of atypical cholinesterase, the onset is also slower. ${ }^{4}$ Similarly, the onset of action of mivacurium is considerably increased in the presence of atypical plasma cholineseterase. $^{5}$

After iv administration of NMBDs, peak plasma concentrations are achieved almost immediately. However, when subparalyzing doses are given, maximum block may not be achieved for 5-7 min. This delay has led to the concept that the neuromuscular junction lies within a compartment (effect compartment) separate from plasma or central compartment, where drug effect is related to concentration. Access from the central compartment to this effect compartment is controlled by a rate constant, $\mathrm{k}_{\mathrm{ee}}{ }^{6}{ }^{6}$ Onset of action is inversely proportional to $\mathrm{k}_{\mathrm{eo}}$ - drugs with higher $\mathrm{k}_{\mathrm{eo}}$ have a more rapid onset (Table III). ${ }^{\text {? }}$

The time to maximal block is almost independent of dose if $<100 \%$ block is attained. In doses producing total paralysis, the latter is achieved before the maximal effect at the junction. The time to disappearance of twitch decreases with increasing dose. Clinicians using non-depolarizing drugs to facilitate tracheal intubation may use larger doses than necessary to accelerate the production of good/excellent intubating conditions.

\section{Pharmacology of the new drugs}

\section{Rocuronium}

Rocuronium was developed from a series of monoquaternary aminosteroids because of its rapid onset of

TABLE I FDA definitions of neuromuscular blocking drugs according to onset and clinical duration (time to $\mathrm{T}_{25}$ ) after $2 \times \mathrm{ED}_{95}$ dose (After FDA, 19959)

\begin{tabular}{llllllll}
\hline & \multicolumn{2}{c}{ ONSET $-\min$} & & \multicolumn{3}{c}{ CLINICAL DURATION $-\min$} \\
\hline Ultra-rapid & Rapid & Inter-mediate & Slow & Ultra-short & Short & Inter-mediate & Long \\
$<1$ & $1-2$ & $2-4$ & 24 & $<4$ & $4-20$ & $20-50$ & $>50$ \\
\hline
\end{tabular}

From the Department of Anesthesia, Vancouver Hospital \& Health Sciences Centrc, 910 West 10th Avenue, Vancouver, B.C. V5Z 4E3 Canada. 
action and absence of cardiovascular side effects in animals. In humans, it is about one sixth as potent as vecuronium and has a more rapid onset of action, although this is slower than after succinylcholine. ${ }^{8}$ Nevertheless, tracheal intubating conditions $60 \mathrm{sec}$ after rocuronium $\left(0.6 \mathrm{mg} \cdot \mathrm{kg}^{-1}\left[2 \times \mathrm{ED}_{95}\right]\right)$ were similar to those produced by succinylcholine $\left(1 \mathrm{mg} \cdot \mathrm{kg}^{-1} \times\right.$ $\left.\left.E_{95}\right]\right) .{ }^{9}$ Optimal intubating conditions after rocuronium, as for other neuromuscular relaxants, occur before maximal block is obtained in the peripheral thumb muscles probably because the laryngeal muscles have an earlier onset of effect. ${ }^{10}$ When given in large doses, 1.2 $\mathrm{mg} \cdot \mathrm{kg}^{-1}$, intubation conditions $30 \mathrm{sec}$ after administration were similar to those after $1.5 \mathrm{mg} \cdot \mathrm{kg}^{-1}$ succinylcholine although the clinical duration was prolonged to $46 \mathrm{~min} .{ }^{11}$ Apart from its more rapid onset of action, the pharmacodynamic behaviour of rocuronium is similar to vecuronium in duration, recovery and reversal. It is potentiated by inhalational anesthetics and the onset and duration of action are prolonged in the elderly. Rocuronium is excreted in the urine and its elimination is decreased in patients with renal failure.

\section{Mivacurium}

Mivacurium is a bisquaternary benzylisoquinoline compound consisting of three stereoisomers: trans-

TABLE II Typical neuromuscular activity of non-depolarizing blocking drugs.

Potency $\left(\mathrm{ED}_{95}\right)$, Onset to maximum effect, $25-75 \%$ Recovery. Index (RI), and time to $25 \% \mathrm{~T}_{1}$ recovery $\left(\mathrm{T}_{90}\right)$ after $2 \times \mathrm{ED}_{95}$ dose in adults.

\begin{tabular}{|c|c|c|c|c|}
\hline \multirow[t]{2}{*}{ Recovery } & \multicolumn{2}{|c|}{$\begin{array}{l}\mathrm{ED}_{95} \mathrm{\mu g} \cdot \mathrm{kg}^{-1} \\
\text { Recovery } 25 \% \mathrm{~T}_{3}\end{array}$} & \multirow[t]{2}{*}{ Onset } & \multirow{2}{*}{$\begin{array}{l}25-75 \% \\
\min \end{array}$} \\
\hline & Min & index - & & \\
\hline Rapacuronium & 750 & $1-1.5$ & $10-15$ & $12-20$ \\
\hline dTC & 500 & $5-6$ & $25-35$ & $70-90$ \\
\hline Atracurium & 200 & $5-6$ & $10-15$ & $25-35$ \\
\hline Cisatracurium & 50 & $7-8$ & $8-9$ & $25-30$ \\
\hline Doxacurium & 25 & $10-14$ & $30-50$ & $80-100$ \\
\hline Metocurine & 280 & $4-6$ & $30-40$ & $80-90$ \\
\hline Mivacurium & $80-150$ & $2-3$ & $10-15$ & $15-20$ \\
\hline Pancuronium & 60 & $4-5$ & $25-30$ & $50-60$ \\
\hline Pipecuronium & 60 & $5-6$ & $30-40$ & $80-90$ \\
\hline Rocuronium & 300 & $2 \cdot 3$ & $10-15$ & $25-35$ \\
\hline Vecuronium & 80 & $4-5$ & $10-15$ & $25-35$ \\
\hline
\end{tabular}

TABLE III Relationship between onset of action and $k_{\mathrm{eo}} \cdot \mathbf{Q}$

\begin{tabular}{lll}
\hline & \multicolumn{2}{c}{$k_{e 0}\left(\mathrm{~min}^{-1}\right)$} \\
& adductor pollicis & laryngeal adductors \\
\hline Rapacuronium & 0.41 & 0.63 \\
Rocuronium & 0.17 & 0.26 \\
Vecuronium & 0.12 & 0.18 \\
\hline
\end{tabular}

trans (57.4\%), cis-trans (36.2\%) and cis-cis (6.4\%) of which the last is pharmacologically inactive. It is a potent, non- depolarizing relaxant $\left(\mathrm{ED}_{95}: 60-80\right.$ $\mu \mathrm{g} \cdot \mathrm{kg}^{-1}$ in adults ${ }^{12}$ and $90-100 \mu \mathrm{g} \cdot \mathrm{kg}^{-1}$ in children, ${ }^{13}$ (Table II). The onset of action is not as rapid as succinylcholine but recovery is quick due to metabolism by plasma cholinesterase. The rate of recovery is twice as rapid as that from vecuronium or atracurium and is similar whether administered by bolus or by continuous infusion to maintain the neuromuscular block. Recovery is so rapid that acceleration by anticholinesterases is very small so that routine reversal may not be necessary. However, if patients are transferred to PACU soon after the end of surgery, they may exhibit residual weakness if reversal agents are avoided. ${ }^{14}$ Edrophonium is preferred to neostigmine as the latter inhibits plasma cholinesterase and may prolong the block. Recovery is considerably prolonged (> six hours) in patients with atypical plasma cholinesterase $^{27}$ even after small test doses of 0.014 $\mathrm{mg} \cdot \mathrm{kg}^{-1,5}$ and the infusion rate required to maintain constant block is correlated with the plasma cholinesterase activity. Mivacurium is rapidly cleared from the plasma but more slowly in patients undergoing hepatic transplantation due to the decreased plasma cholinesterase synthesis. Mivacurium is potentiated by isoflurane and by enflurane. If mivacurium is given rapidly, over 10-15 sec, it is followed by a brief, $<5 \mathrm{~min}$, decrease in systolic blood pressure, cutaneous erythema and histamine release. ${ }^{15}$ Usually, the hypotension is mild but in some patients may be severe enough to require treatment with vasopressors.

\section{Cisatracurium}

Atracurium consists of 10 stereoisomers: cisatracurium is one and comprises approximately $15 \%$ of the mixture. It is approximately four times as potent as atracurium (Table II) and has been developed because it does not release histamine. There are no clinical cardiovascular effects in doses exceeding the clinical range and it does not produce cutaneous flushing. ${ }^{16}$ It has a slightly slower onset than atracurium, probably a result of its increased potency, but a slightly more rapid recovery. It is metabolized, like atracurium, by Hoffmann clearance. However, only $23 \%$ of the elimination is organ dependent compared with $61 \%$ for atracurium. Cisatracurium, like atracurium, demonstrates considerable synergism with aminosteroids such as rocuronium. ${ }^{17}$ Cisatracurium has few advantages over atracurium other than the absence of cardiovascular effects and histamine release. Its current popularity in North America is more a reflection of attractive pricing than superior pharmacological activity. 
TABLE IV Intubation $90 \mathrm{sec}$ after succinylcholine or mivacurium ${ }^{37}$

\begin{tabular}{|c|c|c|c|c|c|}
\hline & \multirow[b]{2}{*}{$n$} & \multicolumn{2}{|c|}{$\begin{array}{c}\text { Intubation } \\
@ 90 \text { sec }\end{array}$} & \multicolumn{2}{|c|}{$\begin{array}{c}\text { TOF } \\
\text { count }\end{array}$} \\
\hline & & Excellent & Good & 0 & 4 \\
\hline $\begin{array}{l}\text { Succinylcholine } 1 \mathrm{mg} \cdot \mathrm{kg}^{-1} \text { : } \\
\text { dTc } 50 \mu \mathrm{\mu g} \cdot \mathrm{kg}^{-1}-3 \mathrm{~min} \\
\text { Mivacurium } 0.25 \mathrm{mg} \cdot \mathrm{kg}^{-1} \text { divided: }\end{array}$ & 97 & 81 & 10 & 53 & 43 \\
\hline $0.15 \& 0.1 \mathrm{mg} \cdot \mathrm{kg}^{-1} @ 30 \mathrm{sec}$ & 91 & 51 & 38 & 2 & 88 \\
\hline
\end{tabular}

\section{Rapacuronium}

The latest in the aminosteroid series of neuromuscular relaxants is rapacuronium and it is currently undergoing pre-clinical evaluation. Preliminary studies suggest that the $\mathrm{ED}_{95}$ is approximately $1 \mathrm{mg} \cdot \mathrm{kg}^{-1} \cdot{ }^{18}$ Doses of $2 \mathrm{mg} \cdot \mathrm{kg}^{-1}$ produce good-excellent intubating conditions in $90 \%$ of adults with a mean clinical duration of $18 \mathrm{~min}$ and recovery to $70 \%$ TOF in $45 \mathrm{~min} .{ }^{19}$ Onset and recovery are slower in elderly patients. An unique aspect of rapacuronim is the observation that the block can be reversed soon after administration. After $1.5 \mathrm{mg} \cdot \mathrm{kg}^{-1}$ followed by $0.07 \mathrm{mg} \cdot \mathrm{kg}^{-1}$ neostigmine 2 min later return to $\mathrm{TOF}_{0.7}$ occurred in $16-18 \mathrm{~min} .{ }^{20}$

\section{Rapid Onset Clinical Strategies}

\section{Succinylcholine}

Despite the frequency of severe complications, succinylcholine remains the NMBD most frequently used to facilitate tracheal intubation, particularly in emergency situations in the presence of a full stomach. In addition, it is the least expensive option. However, the difficulty in recognising children with undiagnosed Duchenne muscular dystrophy which results in hyperkalemia and death after succinylcholine has provided some urgency in seeking a replacement for succinylcholine.

\section{Non-depolarizing relaxant}

The rapid onset of rocuronium, although not as quick as succinylcholine, produces good/excellent intubating conditions within $60 \mathrm{sec}$ that are indistinguishable from those of succinylcholine. However, the duration of action is much longer - clinical duration after an intubating dose of $0.6 \mathrm{mg} \cdot \mathrm{kg}^{-1}$ is $30-40 \mathrm{~min}$.
Increasing the dose of any non-depolarizing relaxant accelerates the appearance of maximum block and acceptable intubating conditions but at the price of considerable delay in recovery.

\section{Divided doses - "priming", "timing"}

Although onset can be accelerated with small "priming" doses of non-depolarizing relaxant three minutes before the main dose, the effect is small. Priming carries the risk of aspiration and difficulty in swallowing, and visual disturbances are uncomfortable for the patient. The practice has largely been superseded by the introduction of rocuronium.

Attempts to make use of the rapid recovery of mivacurium have included administration of 0.15 and $0.1 \mathrm{mg} \cdot \mathrm{kg}^{-1}, 30 \mathrm{sec}$ apart. ${ }^{21}$ After induction of anesthesia with propofol, intubating conditions after $\mathbf{9 0}$ sec were similar after succinylcholine, preceded by a defasciculating dose of $d$-tubocurarine, and divided dose mivacurium (Table IV).

Using the "timing principle" rocuronium, 0.6 $\mathrm{mg} \cdot \mathrm{kg}^{-1}$, is given before anesthesia which is induced as soon as ptosis is observed. Using this technique, tracheal intubation was performed at 45 or $60 \mathrm{sec}$ and was achieved with similar conditions as after 1.5 $\mathrm{mg} \cdot \mathrm{kg}^{-1}$ succinylcholine preceded by vecuronium. ${ }^{22}$

\section{Early reversal}

The experimental rapid onset, intermediate duration relaxant, rapacuronium, has a similar onset of block as rocuronium. However, when administered in a bolus of $1.5 \mathrm{mg} \cdot \mathrm{kg}^{-1} \quad$ (c. $\quad 1.5 \quad-\quad 2 \quad \times \quad \mathrm{ED}_{95}$ )during $\mathrm{N}_{2} \mathrm{O} / \mathrm{O}_{2}$ /halothane anesthesia, ${ }^{7}$ reversal of the block with neostigmine two minutes after its administration produced an onset and recovery profile that was similar to that of succinylcholine ${ }^{19}$ (Table V). Further North American experience demonstrated that, under balanced anesthesia, reversal of $1.5 \mathrm{mg} \cdot \mathrm{kg}^{-1}$ at two or five minutes led to recovery of TOF 0.7 in $16-18 \mathrm{~min}^{20}$

\section{Residual neuromuscular block}

In 1979, Viby-Mogensen and his colleagues demonstrated a high incidence of residual neuromuscular blockade in patients in the Post-Anesthesia Care Unit (PACU). ${ }^{23}$ They examined 72 patients, who had

TABLE V Onset and Recovery after succinylcholine or rapacuronium with/without reversal at $2 \mathrm{~min}^{38}$

\begin{tabular}{|c|c|c|c|c|c|}
\hline & $n$ & Onset - sec & $T_{25}-\min$ & $T_{90}-\min$ & $T_{O F_{0.7}}-\min$ \\
\hline Sux $1 \mathrm{mg} \cdot \mathrm{kg}^{-1}$ & 15 & $67 \pm 20$ & $8.0 \pm 2.5$ & $10.6 \pm 3.3$ & - \\
\hline $\operatorname{Rap} 1.5 \mathrm{mg} \cdot \mathrm{kg}^{-1}$ & 15 & & $8.0 \pm 1.9$ & $16.4 \pm 5.8$ & $24.1 \pm 6.2$ \\
\hline Rap $1.5 \mathrm{mg} \cdot \mathrm{kg}^{-1}+$ neo & 15 & $83 \pm 38$ & $5.7 \pm 0.6$ & $10.8 \pm 3.5$ & $11.6 \pm 1.4$ \\
\hline
\end{tabular}


received a variety of long-acting relaxants ( $d$-tubocurarine, gallamine and pancuronium), after the anesthetist had left the parient to the care of the PACU staff. In $30(42 \%)$, the TOF ratio of the adductor pollicis was less than 0.7 although 67 had received neostigmine to reverse the block. Of the 68 who were sufficiently awake and cooperative, 16 (24\%) were unable to maintain a five-second head lift. Other studies, performed in several countries have reported a similar high incidence of residual paralysis although the incidence of weakness ( $\mathrm{TOF}<0.7$ ) was reduced to less than $10 \%$ when the intermediate agents, atracuri$\mathrm{um}$ and vecuronium, were used. ${ }^{24}$

The decreased incidence of residual block when intermediate or short duration relaxants are used has led to the gradual disappearance of long-acting relaxants such as pancuronium, $d$-tubocurarine, or doxacurium despite the potential reduction in anesthetic costs that might be achieved with generic pancuronium. ${ }^{25}$ However, Kopman et al. have suggested that if neuromuscular blocking drug administration is titrated carefully with continuous neuromuscular monitoring, then residual block is not seen, after the use of either mivacurium or pancuronium. ${ }^{26}$ However, on closer inspection, it appears that patients in Kopman's study did not reach the PACU until $30 \mathrm{~min}$ after reversal of block. In most previous studies patients reached the PACU within $15 \mathrm{~min}$, or less, after reversal. The more time that is allowed and the less intense the block that is antagonised, the less likely is residual block to occur.

\section{Clinical Importance}

Only recently, has the clinical importance of residual block been proved. In volunteers receiving continuous infusion of atracurium or vecuronium, mild degrees of block have been shown to be associated with ventilatory and esophageal disturbances. Eriksson et al. showed, in awake volunteers receiving a continuous infusion of vecuronium to maintain constant $n-m$ block, that at TOF of $0.6-0.7$, the ventilatory response to hypoxia, but not hypercapnia, was impaired and did not return to normal until TOF $\geq 0.9 .^{27}$ The likely cause is that neuromuscular blocking drugs impair the nicotinic carotid body receptors. In a similar study, the same authors showed reduced pharyngeal muscle coordination and shortened pharyngeal bolus transit time. Six of 14 volunteers demonstrated laryngeal penetration by videoradiography at TOF $0.6-0.8 .^{28}$ Finally, in a large, controlled study of post-operative pulmonary complications in 693 subjects randomised to receive pancuronium, vecuronium or atracurium for abdominal, gynecological or orthopedic surgery Berg et al. showed
TABLE VI Postoperative pulmonary complications and choice of relaxant. ${ }^{29}$

\begin{tabular}{lllllll}
\hline & \multicolumn{3}{c}{ Pancuronium, $n=226$} & \multicolumn{2}{c}{ Atra or Vec, $n=450$} \\
\hline & & Pts with POPC & & \multicolumn{2}{c}{ Pts with POPC } \\
& $\mathrm{n}$ & $\mathrm{n}$ & $\%$ & $\mathrm{n}$ & $\mathrm{n}$ & $\%$ \\
TOF 20.7 & 167 & 8 & 4.8 & 426 & 23 & 5.4 \\
TOF $<0.7$ & 59 & 10 & 16.9 & 24 & 1 & 4.2 \\
\hline
\end{tabular}

that $\mathrm{TOF}<0.7$ after pancuronium was a potential risk factor for development of POPC (Table VI). ${ }^{29}$

\section{Summary}

The development of new, intermediate neuromuscular blocking drugs has allowed not only the near replacement of succinylcholine and its multitude of side effects but also the avoidance of residual block after long-acting relaxants such as pancuronium. However, such developments have a price.

\section{Cost of relaxants}

Several of the Cost Minimization Analyses concerning anesthesia drugs have been concerned with neuromuscular blocking drugs. By converting from the intermediate drugs - atracurium, vecuronium - to pancuronium, the possibility of large savings without added risk have been claimed. ${ }^{25}$ Atracurium and vecuronium are considered to be expensive because of the large price differential between the cost of these agents and pancuronium or d-tubocurarine at the time of their introduction; current availability of generic pancuronium; and the uncontrolled use of very large quantities of muscle relaxants, mainly vecuronium, in the ICU. However, any return to the greater use of pancuronium in place of atracurium or vecuronium is likely to be associated with residual paralysis in the Post Anesthetic Recovery Room even after intraoperative neuromuscular monitoring and reversal of their effects.

The acquisition costs of relaxant drugs to facilitate tracheal intubation (approx $2 \times \mathrm{ED}_{95}$ ) varies from $\$ 1$ for succinylcholine to $\$ 13-\$ 16$ for atracurium, vecuronium or mivacurium. The cost of maintaining adequate relaxation during surgery (> 90\% block) varies from $\$ 6$ per hr for succinylcholine to $\$ 2.25$ for pancuronium and $\$ 8$ for atracurium or vecuronium. Costs of reversal agents are similar for atropine-neostigmine and atropine-edrophonium (\$1.50) which is a little less than for glycopyrrolate-neostigmine $(\$ 2.50)$. However, such data require considerable interpretation to be useful. For example, how can the cost of muscle pains after succinylcholine or the morbidity of prolonged weakness in 
TABLE VII "Best Practice" consensus group guidelines. (After Lubtsky et al. ${ }^{16}$ )

\begin{tabular}{|c|c|c|}
\hline & Primary Choice & Options \\
\hline IV Induction & Thiopentone & $\begin{array}{l}\text { Propofol } \\
\text { if history of PONV }\end{array}$ \\
\hline Muscle relaxant & Succinylcholine & $\begin{array}{l}\text { Rocuronium or vecuroni- } \\
\text { um }\end{array}$ \\
\hline Opioid & $\begin{array}{l}\text { Pancuronium } \\
\text { Fentanyl }\end{array}$ & $\begin{array}{l}\text { only if } \mathrm{HR} \text { a concern } \\
\text { Sufentanil if high dose } \\
\text { technique } \\
\text { + early extubation }\end{array}$ \\
\hline Inhalation & $\begin{array}{l}\text { Isoflurane } \\
\text { FGF } \leq 1 \mathrm{~L} / \mathrm{min}\end{array}$ & \\
\hline IV Fluids & $\begin{array}{l}\text { Normal saline or } \\
\text { Ringer's Lactate }\end{array}$ & $\begin{array}{l}\text { Colloid if massive hem or } \\
\text { endothelial leak }\end{array}$ \\
\hline
\end{tabular}

the recovery room after long-acting relaxants be estimated? Drug costs depend on the number of ampoules opened and not on the amount of drug given. Savings might be possible if a sufficient number of anesthesiologists converted to using short-acting relaxants such as mivacurium allowing earlier discharge from the Recovery Room but these would only be achieved if the number of nursing staff in the area was decreased.

\section{Cost Reduction Strategies}

Several strategies have been used in an attempt to reduce cost during anesthesia. Almost all have examined drug costs and a variety of educational programs, mandatory practice guidelines, and feedback of individual performance data. In general, educational programs have had limited success in maintaining a pattern of low cost prescription. For example Johnstone and Jozefczyk were able to produce considerable savings during the education period but, within two months, drug costs had returned at least to their previous level. ${ }^{30}$ In a more imaginative approach at Duke University, practice guidelines for drug use during anesthesia were generated by physicians (Table VII). A drug distribution process was developed (i.e. drug availability was controlled), and adherence to guidelines was noted using an automated anesthesia record keeper (Arkive $(8) .{ }^{31}$ Clinical outcome data in the PACU and times indicative of patient flow were collected. ${ }^{32}$ With this system, the cost per case (\$66.08US)[\$24.52 per hr] in 1994 decreased to $\$ 32[\$ 11.46]$ in 1996 and, apparently, have been maintained at this level without any measurable deterioration in patient outcome. Previous educational attempts produced little change in the pattern of drug use. However, these results were achieved at some cost. Drug choice was restricted and the costs should
TABLE VIII Cost per minute of various activities:

\begin{tabular}{ll}
\hline & \$per minute \\
\hline Anesthesia drugs & $\$ 0.5$ \\
Operating room & $\$ 10$ \\
Boeing 747 on runway & $\$ 80$ \\
Anesthesiology fee & $\$ 2$ \\
\hline
\end{tabular}

also include the personnel (Physicians generating guidelines, Arkive purchase $(\$ 60,000=\$ 15,000$ per site), computer programming, on-going data collection and distribution. No doubt the choice of some drugs for the "best-practice" consensus guidelines might be different as new data concerning perioperative complications are reported. For example, it would be difficult to support the continued use of pancuronium after the demonstration, in Copenhagen, of the considerable increase in Postoperative Pulmonary Complications following its use compared with that after atracurium or vecuronium. The outcome analysed at Duke in the PACU may not have been able to collect such information. Interestingly, the cost of anesthesia drugs in Vancouver in 1996 without direct control was \$40CAN! It is important in examining each report to compare the pattern of surgery and the pre-testing use of drugs with that in one's own hospital to determine whether such reductions can be achieved elsewhere. Berman and Simon reported that the cost of anesthetic drugs by residents was reduced by an individual cost feedback system that compared the individual drug use and cost, with that of the department average. Not surprisingly, the use of more expensive drugs decreased and follow-up, three months later, showed considerable rebound in cost.

\section{Perspective}

At a time of cost awareness, it is perhaps appropriate to remember that the acquisition cost of anesthesia drugs is likely to amount to approximately $0.25 \%$ of the total hospital budget and is only a fraction of the cost of running an operating room.(Table VIII)

\section{Conclusion}

In the development of new neuromuscular blocking drugs the anesthesiologist is now provided with drugs that are almost free of unwanted effects, have a time course of action that allows great control of their activity and, in most cases, allow us to substitute them for succinylcholine. Muscle Relaxants are Cheap. 
References

1 Bedford RE. From the FDA. Anesthesiology 1995; 82: $33 \mathrm{~A}$.

2 Bowman WC, Rodger IW, Houston J, Marshall RJ, McIndewar I. Structure: action relationships among some desacetoxy analogues of pancuronium and vecuronium in the anesthetized cat. Anesthesiology 1988; 69: 57-62.

3 Magorian $T$, Flannery KB, Miller RD. Comparison of rocuronium, succinylcholine, and vecuronium for rapid-sequence induction of anesthesia in adult patients. Anesthesiology 1993; 79: 913-8.

4 Hickey DR, O, Connor JP, Donati F. Comparison of atracurium and succinylcholine for electroconvulsive therapy in a patient with atypical plasma cholinesterase. Can J Anaesth 1987; 34: 280-3.

5 Vanlinthout LE, Bartels CF, Lockridge $O$, Callens $K$, Booij $L H$. Prolonged paralysis after a test dose of mivacurium in a patient with atypical serum cholinesterase. Anesth Analg 1998; 87: 1199-202.

6 Sheiner LB, Stanski DR, Vozeh S, Miller RD, Ham J. Simultaneous modelling of pharmacokinetics and pharmacodynamics: application to d-tubocurarine. Clin Pharmacol Ther 1979; 25: 358-71.

7 Wright PMC, Brown $R$, Lau M, Fisher DM. A pharmacodynamic explanation for the rapid onset/offset of rapacuronium bromide. Anesthesiology 1999; 90: 16-23.

8 Wierda JMKH, Kleef UW, Lambalk LM, Kloppenburg $W D$, Agoston $S$. The pharmacodynamics and pharmacokinetics of Org 9426, a new non-depolarizing neuromuscular blocking agent, in patients anesthetized with nitrous oxide, halothane and fentanyl. Can J Anaesth 1991; 38: 430-5.

9 Phringer FK, Khuenl-Brady KS, Koller J, Mitterschiffthaler $G$. Evaluation of the endotracheal intubating conditions of rocuronium (ORG 9426) and succinylcholine in outpatient surgery. Anesth Analg $1992 ; 75: 37-40$.

10 Meistelman C, Plaud B, Donati F. Rocuronium (ORG 9426) neuromuscular blockade at the adductor muscles of the larynx and adductor pollicis in humans. Can J Anaesth 1992; 39: 665-9.

11 Mazurak AJ, Re B, Hann S, Kim JI, Castro B, Coté CJ. Rocuronium versus succinylcholine: are they equally effective during rapid-sequence induction of anesthesia. Anesth Analg 1998; 87: 1259-62.

12 Saparese J, Ali HH, Basta SJ, et al. The clinical neuromuscular pharmacology of mivacurium chloride (BW B1090U): a short-acting nondepolarizing ester neuromuscular blocking drug. Anesthesiology 1988; 68: 723-32.

13 Goudsouzian NG, Alifimoff JK, Everly $C$, at al. Neuromuscular and cardiovascular effects of mivacurium in children. Anesthesiology 1989; 70: 237-42.
14 Bevan DR, Kabwaji R, Ansermino JM, et al. Residual block after mivacurium with or without edrophonium reversal in adults and children. Anesthesiology 1996; 84: 362-7.

15 Saparese J, Ali HH, Basta SJ, et al. The cardiovascular effects of mivacurium chloride (BW Bl090U) in patients receiving nitrous oxide-opiate-barbiturate anesthesia. Anesthesiology 1989; 70: 386-94.

16 Lepage J- $\Upsilon$, Malinovsky J-M, Malinge $M$, et al. Pharmacodynamic dose-response and safety study of cisatracurium (51W89) in adult surgical patients during $\mathrm{N}_{2} \mathrm{O}-\mathrm{O}_{2}$-opioid anesthesia. Anesth Analg 1996; 83: 823-9.

17 Naguib $M$, Samarkandi AH, Ammar A, Elfaqih SR, Al-Zabrani, Turkistani $A$. Comparative clinical pharmacology of rocuronium, cisatracurium, and their combination. Anesthesiology 1998; 89: 1116-24.

18 Kabwaji $R$, Bevan DR, Bikhazi G, et al. Dose-ranging study in younger adult and elderly parients of $O R G$ 9487, a new rapid-onset, short-duration muscle relaxant Anesth Analg 1997; 84: 1011-8.

19 Wierda JM, van den Broek L, Proost JH, Verbaan BW, Hennis PJ. Time course of action and endotracheal intubating conditions of Org 9487, a new short-acting steroidal muscle relaxant; a comparison with succinylcholine. Anesth Analg 1993; 77: 579-84.

20 Purdy R, Bepan, DR, Fowler C, Donati F, Lichtor $J L$. Early reversal of rapacuronium with neostigmine. Anesthesiology (accepted for publication).

21 Ali HH, Lien CA, Witkowski T, et al. Efficacy and safety of divided dose administration of mivacurium for a 90 second tracheal intubation. J Clin Anesth 1996; 8: 276-81.

22 Sieber TJ, Zbinden AM, Curatolo $M$, Shorten GD. Tracheal intubation with rocuronium using the "timing principle". Anesth Analg 1996; 86: 1137-40.

23 Viby-Mogensen J, Jørgensen BC, Ørding $H$. Residual curarization in the recovery room. Anesthesiology $1979 ; 50: 539-41$.

24 Bevan DR, Smith CE, Donati F. Postoperative neuromuscular blockade: a comparison between atracurium, vecuronium, and pancuronium. Anesthesiology 1988; 69: 272-6.

25 Orkin FK. Moving toward value-based anesthesia care $\mathrm{J}$ Clin Anesth 1993; 5: 91-8.

26 Kopman AA, Ng J, Zank LM, Neuman GG, Yee PS. Residual postoperative paralysis. Pancuronium versus mivacurium, does it matter? Anesthesiology 1996; 85: 1253-9.

27 Eriksson LI, Sundman E, Olsson R, et al. Functional assessment of the pharynx at rest and during swallowing in partially paralyzed humans. Anesthesiology 1997; 87: 1045-43 
28 Eriksson LI, Lennmarken C, Johnson A. Attenuated ventilatory response to hypoxemia after vecuronium induced neuromuscular block. Acta Anaesthesiol Scand 1992; 36: 710-5.

29 Berg H, Viby-Mogensen J, Roed J, et al. Residual neuromuscular block is a risk factor for postoperative pulmonary complications. Acta Anaesthesiol Scand 1997; 41: 1095-103.

30 Jobnstone RE, Jozefczyk KG. Costs of anesthetic drugs: experiences with a cost education trial. Anesth Analg 1994; 78: 766-71.

31 Lubarsky DA, Glass PSA, Ginsberg $B$, et al. The successful implementation of pharmaceutical practice guidelines. Anesthesiology 1997; 86: 1145-60.

32 Lubarsky DA, Sanderson IC, Gilbert WC, et al. Using an anesthesia information management system as a cost containment tool. Anesthesiology 1997; 86: 1161-9. 


\section{Les nouveaux myorela- xants : en valent-ils le coût?}

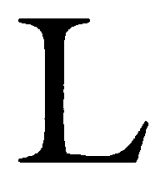

A plupart des programmes de recherche actuels sur les médicaments neuromusculaires tentent de trouver un substitut possible à la succinylcholine dont le début d'action est rapide mais l'effet de courte durée. C'est ce qui a amené la FDA à réévaluer et à redéfinir les myorelaxants d'après leur rapidité et leur durée d'action en utilisant une dose de $2 \times \mathrm{ED}_{95}$ (Table I). ${ }^{\mathrm{l}}$ Tout nouveau médicament myorelaxant introduit en clinique devra sans aucun doute n'avoir pratiquement aucune action cardiovasculaire. Nous voulons présenter ici une description de ce qui guide l'élaboration des nouveaux médicaments et une revue de la pharmacologie des myorelaxants à action intermédiaire nouvellement offerts : le rocuronium, le mivacurium, le cisatracurium et le rapacuronium. L'un des problèmes de développement du «myorelaxant idéal» est le coût ; nous tenterons de le mettre en perspective.

\section{Début d'action}

L'action du médicament dépend de l'arrivée au récepteur d'un nombre suffisant de molécules qui, soit produisent la dépolarisation de la plaque motrice (myorelaxant dépolarisant), soit empêchent l'acétylcholine d'atteindre assez de récepteurs et d'assurer ainsi la transmission neuromusculaire (myorelaxant non dépolarisant). La rapidité d'action dépend surtout de la vitesse d'arrivée du médicament à la plaque motrice. Elle est modifiée par la puissance du médicament et par son métabolisme. Le début d'action avec les non dépolarisants est inversement proportionnelle à leur puissance. ${ }^{2}$ Ainsi, parmi les cinq médicaments récemment adoptés - doxacurium, mivacurium, pipécuronium, rocuronium, cisatracurium - le plus puissant est le doxacurium $\left(\mathrm{ED}_{50} 0,015 \mathrm{mg} \cdot \mathrm{kg}^{-1}\right)$ et il est le plus lent à agir $(10-15 \mathrm{~min})$. Le moins puissant, le rocuronium $\left(\mathrm{ED}_{50}\right.$ $\left.0,15 \mathrm{mg} \cdot \mathrm{kg}^{-1}\right)$, est le plus rapide $(1,5-2,5 \mathrm{~min})$ et semble être à peu près aussi rapide que la succinylcholine ${ }^{3}$ (Table II). L'action prompte de la succinylcholine est liée à la rapidité de son métabolisme et de sa clairance plasmatique. Quand le métabolisme est altéré, en présence de cholinestérase atypique par exemple, le début d'action est ralenti. ${ }^{4}$ Il en va de même avec le mivacurium. 5

Après l'administration iv de myorelaxant, les concentrations plasmatiques maximales sont presque immédiatement atteintes. Cependant, l'administration de doses insuffisantes pour paralyser ne permettra un blocage maximal qu'après 5-7 minutes. Ce qui a fait penser que la jonction neuromusculaire se situe à l'intérieur d'un compartiment (compartiment d'effet) séparé du plasma ou du compartiment central où l'effet du médicament dépend de sa concentration. L'accès au compartiment d'effet, à partir du compartiment central, est contrôlé par une constante de transfert $k_{e o} \cdot{ }^{6}$ La rapidité d'action est inversement proportionnelle à $\mathrm{k}_{\mathrm{eo}}$ - les médicaments qui ont une $\mathbf{k}_{\mathrm{eo}}$ élevée ont un début d'action plus rapide (Table III). ${ }^{7}$

Le temps nécessaire pour atteindre le blocage maximal est presque indépendant de la dose quand la paralysie n'est pas complète. Avec des doses qui paralysent complètement, le blocage maximal est atteint avant l'effet maximal à la jonction neuromusculaire. Le temps nécessaire à la disparition des réactions musculaires (twitch) diminue avec l'augmentation de la dose. Les cliniciens qui utilisent des médicaments non dépolarisants pour faciliter l'intubation endotrachéale peuvent se servir de doses plus importantes que nécessaire pour que de bonnes, et même d'excellentes, conditions d'intubation soient plus rapidement établies.

TABLE I Définitions des myorelaxants selon leur début d'action et leur durée clinique (temps vers $\mathrm{T}_{25}$ ) après une dose de $2 \times \mathrm{ED}_{95}$ (FDA, 1995')

\begin{tabular}{llllllll}
\hline \multicolumn{3}{c}{$D E ́$ BUT $-\min$} & & \multicolumn{3}{c}{ DURÉE CLINIQUE - min } \\
\hline Ultra-rapide & Rapide & Intermédiaire & Lent & Très courte & Courte & Intermédiaire & Longue \\
$\leq 1$ & $1-2$ & $2 \cdot 4$ & 24 & $<4$ & $4-20$ & $20-50$ & $>50$. \\
\hline
\end{tabular}




\section{Pharmacologie des nouveaux médicaments Rocuronium}

Le rocuronium a été élaboré à partir de séries d'aminostéroïdes monoquaternaires en raison de sa rapidité d'action et de l'absence d'effets secondaires cardiovasculaires chez les animaux. Chez les humains, sa puissance équivaut à un sixième environ de celle du vécuronium et il a une plus grande rapidité d'action, quoique plus lente que la succinylcholine. ${ }^{8}$ Néanmoins, les conditions d'intubation endotrachéale, $60 \mathrm{~s}$ après l'administration de rocuronium $(0,6$ $\left.\mathrm{mg} \cdot \mathrm{kg}^{-1}\left[2-\mathrm{ED}_{95}\right]\right)$ sont similaires à celles qui sont produites avec la succinylcholine ( $1 \mathrm{mg} \cdot \mathrm{kg}^{-1} \times$ $\left.\left.\mathrm{ED}_{95}\right]\right) .9$ Les conditions optimales d'intubation après le rocuronium, comme avec les autres myorelaxants, se présentent avant que le blocage maximal ne soit atteint dans les muscles périphériques du pouce, sans doute parce que l'effet du médicament est plus rapide sur les muscles laryngés. ${ }^{10}$ Quand on l'administre en fortes doses, $1,2 \mathrm{mg} \cdot \mathrm{kg}^{-1}$, les conditions d'intubation $30 \mathrm{~s}$ après l'administration sont similaires à celles qu'on a observées après $1,5 \mathrm{mg} \cdot \mathrm{kg}^{-1}$ de succinylcholine bien que la durée du bloc se prolonge jusqu'à $46 \mathrm{~min} .{ }^{11}$ Mis à part sa rapidité d'action, le comportement pharmacodynamique du rocuronium est semblable à celui du vécuronium pour la durée, la

TABLE II Activité neuromusculaire typique des myorelaxants non dépolarisants

Puissance $\left(\mathrm{ED}_{95}\right)$, Du début à l'effet maximal, Index de récupération $25-75 \%$ (IR), et le temps pour une récupération de $25 \%$ $\mathrm{T}_{1}\left(\mathrm{~T}_{90}\right)$ après une dose de $2 \times \mathrm{ED}_{95}$ chez les adultes

\begin{tabular}{lllll} 
& \multicolumn{2}{l}{$\mathrm{ED}_{95} \mu \mathrm{\mu g} \cdot \mathrm{kg}^{-1}$} & Début & Index de \\
& \multicolumn{2}{l}{ Récupération $25 \% \mathrm{~T}_{\mathrm{I}}$} & récupération \\
& Min & $25-75 \%-\min$ & $\min$ \\
Rapacuronium & 750 & $1-1,5$ & $10-15$ & $12-20$ \\
dTC & 500 & $5-6$ & $25-35$ & $70-90$ \\
Atracurium & 200 & $5-6$ & $10-15$ & $25-35$ \\
Cisatracurium & 50 & $7-8$ & $8-9$ & $25-30$ \\
Doxacurium & 25 & $10-14$ & $30-50$ & $80-100$ \\
Métocurine & 280 & $4-6$ & $30-40$ & $80-90$ \\
Mivacurium & $80-150$ & $2-3$ & $10-15$ & $15-20$ \\
Pancuronium & 60 & $4-5$ & $25-30$ & $50-60$ \\
Pipécuronium & 60 & $\mathbf{5}-6$ & $30-40$ & $80-90$ \\
Rocuronium & 300 & $2-3$ & $10-15$ & $25-35$ \\
Vécuronium & 80 & $4-5$ & $10-15$ & $25-35$ \\
\hline
\end{tabular}

TABLE III Relation entre le début d'action et la $\mathrm{k}_{\text {eo }} \cdot \mathrm{Q}$

\begin{tabular}{lll}
\hline & \multicolumn{2}{c}{$k_{c o}\left(\mathrm{~min}^{-1}\right)$} \\
& adducteur du pouce & adducteurs laryngés \\
\hline Rapacuronium & 0,41 & 0,63 \\
Rocuronium & 0,17 & 0,26 \\
Vécuronium & 0,12 & 0,18 \\
\hline
\end{tabular}

récupération et le renversement. Il est potentialisé par les anesthésiques administrés par inhalation et, chez les gens âgés, son début d'action et sa durée sont prolongés. Son élimination, dans l'urine, diminue chez les patients atteints d'insuffisance rénale.

\section{Mipacurium}

Le mivacurium est un composé benzylisoquinoléique biquaternaire constitué de trois stéréo-isomères : trans-trans $(57,4 \%)$, cis-trans $(36,2 \%)$ et cis-cis $(6,4$ $\%)$ dont le dernier n'a pas d'action pharmacologique. C'est un curarisant puissant, non dépolarisant $\left(\mathrm{ED}_{95}\right.$ : $60-80 \mu \mathrm{g} \cdot \mathrm{kg}^{-1}$ chez les adultes ${ }^{12}$ et $90-100 \mu \mathrm{g} \cdot \mathrm{kg}^{-1}$ chez les enfants ${ }^{13}$ (Table II). Il n'a pas la rapidité d'action de la succinylcholine, mais permet une récupération rapide, car métabolisé par la cholinestérase plasmatique. La récupération, deux fois plus rapide qu'avec le vécuronium ou l'atracurium, n'est pas influencée par le mode d'administration, en bolus ou en perfusion continue. En fait, la récupération est si rapide que l'accélération produite par l'anticholinestérase est très faible, de sorte que la décurarisation de routine ne sera peut-être pas nécessaire. Toutefois, les patients transférés à la salle de réveil dès la fin de l'opérations peuvent ressentir une faiblesse résiduelle si un décurarisant n'est pas administré. ${ }^{14}$ L'édrophonium est préférable dans ce cas à la néostigmine, puisque cette dernière inhibe la cholinestérase plasmatique et peut prolonger le bloc. La récupération est considérablement prolongée, plus de six heures, chez les patients qui présentent une cholinestérase plasmatique atypique, ${ }^{27}$ même après de faibles doses test de $0,014 \mathrm{mg} \cdot \mathrm{kg}^{-1,5}$, et la vitesse de perfusion nécessaire pour maintenir un bloc constant est en corrélation avec l'activité de la cholinestérase. Le mivacurium est éliminé rapidement du plasma, mais plus lentement chez les patients qui subissent une transplantation hépatique et cela à cause de la synthèse déficiente de cholinestérase plasmatique. Le mivacurium est potentialisé par l'isoflurane et l'enflurane. S'il est administré rapidement, 10-15 s, il s'ensuit une chute brève, $<5 \mathrm{~min}$, de tension artérielle systolique, un érythème cutané et une libération d'histamine. ${ }^{15}$ Habituellement, l'hypotension est modérée, mais chez certains patients elle peut être assez sévère pour exiger un traitement vasopresseur.

\section{Cisatracurium}

L'atracurium comporte 10 stéréo-isomères, le cisatracurium en est un et compte pour $15 \%$ environ du mélange. Environ quatre fois plus puissant que l'atracurium (Table II), il a été commercialisé parce qu'il ne libère pas d'histamine. Il n'y a pas d'effets cardio- 
TABLE IV Intubation $90 \mathrm{~s}$ après la succinylcholine ou le mivacurium $^{37}$

\begin{tabular}{lllllll}
\hline & & \multicolumn{2}{c}{ Intubation } & & \multicolumn{3}{c}{ compte } \\
& $n$ & Excellente & & \multicolumn{2}{c}{ TDQ } \\
& Bonne & 0 & 4 \\
\hline $\begin{array}{l}\text { Succinylcholine } 1 \mathrm{mg} \cdot \mathrm{kg}^{-1}: \\
\text { dTc } 50 \mu \mathrm{\mu g} \cdot \mathrm{kg}^{-1} \cdot 3 \mathrm{~min}\end{array}$ & 97 & 81 & & 10 & 53 & 43 \\
$\begin{array}{l}\text { Mivacurium } 0,25 \mathrm{mg} \cdot \mathrm{kg}^{-1} \\
\text { fractionné : }\end{array}$ & & & & & & \\
$0,15 \& 0,1 \mathrm{mg} \cdot \mathrm{kg}^{-1}$ @ $30 \mathrm{sec}$ & 91 & 51 & 38 & 2 & 88 \\
\hline
\end{tabular}

vasculaires appréciables pour des doses qui dépassent les valeurs cliniques et ne produit pas de rougeur cutanée. ${ }^{16} \mathrm{Il}$ a un début d'action légèrement plus lent que l'atracurium, résultat probable de sa puissance, mais permet une récupération légèrement plus rapide. Il est métabolisé, comme l'atracurium, par la clairance de Hoffmann. Cependant, $23 \%$ seulement de l'élimination dépend de l'organe en comparaison de $61 \%$ pour l'atracurium. Le cisatracurium, comme l'atracurium, démontre une synergie considérable avec les aminostéroïdes comme le rocuronium. ${ }^{17}$ Le cisatracurium a peu d'avantages par rapport à l'atracurium si ce n'est l'absence d'effets cardiovasculaires et la libération d'histamine. Sa popularité actuelle en Amérique du Nord tient plus à son prix attirant qu'à son activité pharmacologique supérieure.

\section{Rapacuronium}

Dernier de la série aminostéroïde des myorelaxants, le rapacuronium est présentement en évaluation préclinique. Des études préliminaires indiquent que la $\mathrm{ED}_{95}$ est approximativement de $1 \mathrm{mg} \cdot \mathrm{kg}^{-1} .^{18}$ Des doses de $2 \mathrm{mg} \cdot \mathrm{kg}^{-1}$ produisent des conditions d'intubation de bonnes à excellentes, chez $90 \%$ des adultes, d'une durée clinique moyenne de $18 \mathrm{~min}$ et la récupération à $70 \%$ du TDQ en 45 min. ${ }^{19}$ Le début d'action et la récupération sont plus lents chez les patients âgés. Le rapacuronium présente un caractère unique en ce que le blocage qu'il produit peut être renversé tôt après l'administration. Après l'administration de $1,5 \mathrm{mg} \cdot \mathrm{kg}^{-1}$ suivie de $0,07 \mathrm{mg} \cdot \mathrm{kg}^{-1}$ de néostigmine 2 min plus tard, le retour au $\mathrm{TDQ}_{0,7}$ s'est produit en $16-18 \mathrm{~min}^{20}$
Stratégies cliniques d'action rapide

Succinylcholine

Malgré la fréquence de sévères complications liées à son usage, la succinylcholine demeure le myorelaxant le plus utilisé pour faciliter l'intubation endotrachéale, en particulier dans les situations d'urgence avec l'estomac plein. En outre, c'est le choix le moins cher. Toutefois, la difficulté à reconnaître la myopathie de Duchenne chez des enfants non diagnostiqués a provoqué de l'hyperkaliémie et la mort après l'emploi de succinylcholine et a fait voir l'urgence de trouver un médicament de remplacement.

\section{Myorelaxant non dépolarisant}

$\mathrm{La}$ rapidité d'action du rocuronium; bien qu'inférieure à celle de la succinylcholine, permet des conditions d'intubation de bonnes à excellentes en moins de $60 \mathrm{~s}$, ce qui est tout à fait comparable à la succinylcholine. Par contre, la durée d'action est beaucoup plus longue, $30-40 \mathrm{~min}$ après une dose d'intubation de $0,6 \mathrm{mg} \cdot \mathrm{kg}^{-1}$. Accroître la dose de tout myorelaxant accélère l'apparition du blocage maximal et la mise en place des conditions acceptables d'intubation, mais au prix d'un délai de récupération important.

\section{Doses fractionnées - «amorfage», "minutage»}

Bien que la rapidité d'action puisse être améliorée avec de petites doses d' «amorçage» de myorelaxant non dépolarisant trois minutes avant la dose principale, l'effet est minime. L'amorçage comporte le risque d'aspiration et des difficultés de déglutition, et des troubles visuels désagréables pour le patient. La pratique a été largement abolie et remplacée avec l'arrivée du rocuronium.

Les essais réalisés dans le but d'utiliser la récupération rapide du mivacurium ont inclus l'administration de 0,15 et $0,1 \mathrm{mg} \cdot \mathrm{kg}^{-1}$, à $30 \mathrm{~s}$ d'intervalle. ${ }^{21}$ Après l'induction de l'anesthésie avec du propofol, les conditions d'intubation étaient, après $90 \mathrm{~s}$, similaires à celles qu'on obtient à la suite de la succinylcholine, précédée par une dose de défasciculation de $d$-tubocurarine, et d'une dose fractionnée de mivacurium (Table IV).

Utilisant le «principe du minutage», $0,6 \mathrm{mg} \cdot \mathrm{kg}^{-1} \mathrm{de}$ rocuronium est administré avant l'anesthésie qui est induite aussitôt que le ptosis est observé. Selon cette

TABLE V Début et récupération après la succinylcholine ou le rapacuronium avec/sans inversion à $2 \mathrm{~min}^{38}$

\begin{tabular}{llllll}
\hline & $n$ & Début - sec & $T_{25}-\min$ & $T_{90}-\min$ & $T D Q_{0,7} \cdot \min$ \\
\hline Sux 1 mg.kg-1 & 15 & $67 \pm 20$ & $8,0 \pm 2,5$ & $10,6 \pm 3,3$ & - \\
Rap 1,5 mg.kg & 15 & & $8,0 \pm 1,9$ & $16,4 \pm 5,8$ & $24,1 \pm 6,2$ \\
Rap 1,5 mg.kg $\mathrm{kg}^{-1}+$ néo & 15 & $83 \pm 38$ & $5,7 \pm 0,6$ & $10,8 \pm 3,5$ & $11,6 \pm 1,4$ \\
\hline
\end{tabular}


technique, l'intubation endotrachéale est réalisée à 45 ou $60 \mathrm{~s}$ et dans des conditions similaires à ce qu'on retrouve après l'administration de $1,5 \mathrm{mg} \cdot \mathrm{kg}^{-1} \mathrm{de}$ succinylcholine précédée de vécuronium. ${ }^{22}$

\section{Décurarisation précoce}

Myorelaxant de durée intermédiaire et de rapidité d'action confirmée par l'expérience, le rapacuronium présente un début d'action similaire à celui du rocuronium. Cependant, quand on l'administre en bolus de $1,5 \mathrm{mg} \cdot \mathrm{kg}^{-1}$ (c. $1,5-2 \times \mathrm{ED}_{95}$ ) pendant une anesthésie au $\mathrm{N}_{2} \mathrm{O} / \mathrm{O}_{2} /$ halothane, ${ }^{7}$ la décurarisation avec de la néostigmine deux minutes après son administration laisse voir un profil de début d'action et de récupération semblable à celui de la succinylcholine 19 (Table V). Une expérience nord-américaine complémentaire a démontré que, sous une anesthésie balancée, la décurarisation de $1,5 \mathrm{mg} \cdot \mathrm{kg}^{-1}$ à deux ou cinq minutes conduit à une récupération du $\mathrm{TDQ}_{0,7}$ en 1618 min. $^{20}$

\section{Blocage neuromusculaire résiduel}

En 1979, Viby-Mogensen et ses collègues ont démontré une forte incidence de blocage neuromusculaire résiduel chez des patients à la salle de réveil ${ }^{23}$ Ils ont examiné 72 patients, qui avaient reçu une variété de myorelaxants à action prolongée ( $d$-tubocurarine, gallamine et pancuronium). Chez 30 d'entre eux ( $42 \%$ ), le ratio du TDQ de l'adducteur du pouce était plus bas que 0,7 même si 67 patients avaient eu de la néostigmine pour renverser le blocage. Parmi les 68 patients suffisamment éveillés et coopératifs, 16 (24\%) n'ont pu maintenir la tête soulevée pendant cinq secondes. D'autres études, réalisées dans différents pays, ont montré une incidence similaire de paralysie résiduelle même si l'incidence de faiblesse (TDQ $<0,7$ ) était réduite à moins de $10 \%$ avec des agents intermédiaires, comme l'atracurium et le vécuronium. ${ }^{24}$

L'incidence décroissante de blocage résiduel en présence de myorelaxants à action brève ou intermédiaire a provoqué la disparition graduelle des myorelaxants de longue durée comme le pancuronium, la $d$ tubocurarine, ou le doxacurium malgré la réduction potentielle du coût de l'anesthésique qu'on pourrait réaliser avec le pancuronium générique. ${ }^{25}$ Cependant, Kopman et coll. ont avancé que l'administration de myorelaxant bien dosé, et sous monitorage continu du bloc neuromusculaire, élimine le blocage résiduel après l'emploi de mivacurium ou de pancuronium. ${ }^{26}$ En y regardant de plus près, on constate que les patients de l'étude de Kopman n'ont été transférés à la salle de réveil que $30 \mathrm{~min}$ après la décurarisation. Dans la plupart des études précédentes, les patients inté-
TABLE VI Complications pulmonaires postopératoires et choix de myorelaxant ${ }^{29}$

\begin{tabular}{lllllll}
\hline & \multicolumn{3}{c}{ Pancuronium, $n=226$} & \multicolumn{3}{c}{ Atra ou Véc, $n=450$} \\
\hline & & Pts avec CPPO & \multicolumn{3}{c}{ Pts avec CPPO } \\
& $\mathrm{n}$ & $\mathrm{n}$ & $\%$ & $\mathrm{n}$ & $\mathrm{n}$ & $\%$ \\
$\mathrm{TDQ} \geq 0,7$ & 167 & 8 & 4,8 & 426 & 23 & 5,4 \\
TDQ $<0,7$ & 59 & 10 & 16,9 & 24 & 1 & 4,2 \\
\hline
\end{tabular}

graient la salle de réveil en $\mathbf{1 5}$ min ou moins après la décurarisation. Plus le temps alloué est long et moins le blocage à contrer est intense, moins il y a de chance qu'un bloc résiduel persiste.

\section{Importance clinique}

Ce n'est que récemment qu'on a prouvé l'importance clinique du bloc résiduel. On a montré chez des volontaires qui recevaient une perfusion continue d'atracurium ou de vécuronium des blocs faibles associés à des désordres ventilatoires et œsophagiens. Eriksson et coll. ont montré, chez des volontaires éveillés recevant une perfusion continue de vécuronium afin de maintenir un blocage neuromusculaire constant, qu'au moment d'un TDQ de 0,6-0,7, la réaction respiratoire à l'hypoxie, mais non à l'hypercapnie, était altérée et ne revenait pas à la normale avant le TDQ 0,9.27 C'est probablement causé par le fait que les myorelaxants altèrent les récepteurs nicotiniques $\mathrm{du}$ glomus carotidien. Dans une étude similaire, les mêmes auteurs ont fait la preuve d'une réduction de la coordination des muscles pharyngiens et un transit écourté du bolus pharyngien. Chez 6 des 14 volontaires, on a observé, par vidéoradiographie, une pénétration laryngienne au TDQ $0,6-0,8 .{ }^{28}$ Enfin, dans une importante étude contrôlée des complications pulmonaires postopératoires chez 693 sujets répartis au hasard et qui ont reçu du pancuronium, du vécuronium ou de l'atracurium pour une intervention abdominale, gynécologique ou orthopédique, Berg et coll. ont montré qu'un TDQ $<0,7$ après le pancuronium représentait un facteur de risque potentiel de développement de CPPO (Table VI). ${ }^{29}$

\section{Résumé}

L'élaboration de nouveaux myorelaxants intermédiaires a permis non seulement le quasi remplacement de la succinylcholine et l'élimination de ses nombreux effets secondaires, mais aussi la possibilité d'éviter un bloc résiduel après l'usage de myorelaxant à action prolongée comme le pancuronium. Malgré tout, de telles innovations ont un prix. 
TABLE VII Recommandations du consensus sur la «Meilleure pratique». (Lubtsky et coll. ${ }^{16}$ )

\begin{tabular}{|c|c|c|}
\hline & Principal choix & Options \\
\hline IV Induction & Thiopental & $\begin{array}{l}\text { Propofol } \\
\text { si antécédents de NVPO }\end{array}$ \\
\hline Myorelaxant & $\begin{array}{l}\text { Succinylcholine } \\
\text { Pancuronium }\end{array}$ & $\begin{array}{l}\text { Rocuronium ou vécuro- } \\
\text { nium } \\
\text { seulement si la FC } \\
\text { préoccupe }\end{array}$ \\
\hline Opioïde & Fentanyl & $\begin{array}{l}\text { Sufentanil si c'est une } \\
\text { technique à forte dose } \\
\text { + extubation précoce }\end{array}$ \\
\hline Inhalation & $\begin{array}{l}\text { Isoflurane } \\
\text { FGF } \leq 1 \mathrm{~L} / \mathrm{min}\end{array}$ & \\
\hline IV Liquides & $\begin{array}{l}\text { Solution salée ou } \\
\text { Lactate de Ringer }\end{array}$ & $\begin{array}{l}\text { Colloïde si hém massive } \\
\text { ou fuite endothéliale }\end{array}$ \\
\hline
\end{tabular}

\section{Le cout des myorelaxants}

Quelques analyses de réduction des coûts, concernant les médicaments anesthésiques, ont porté sur les curarisants. En passant des médicaments à action intermédiaires - atracurium, vécuronium - au pancuronium, on a prétendu qu'il était possible d'épargner sans risque additionnel..$^{25}$ On considère que l'atracurium et le vécuronium sont chers à cause de la grande différence entre le prix de ces agents et celui du pancuronium ou de la d-tubocurarine au moment de leur introduction, de la disponibilité actuelle de pancuronium générique et de l'emploi incontrôlé de grandes quantités de myorelaxants, le vécuronium surtout, dans les USI. Cependant, tout retour à un usage plus fréquent de pancuronium, à la place de l'atracurium ou du vécuronium, sera probablement associé à une paralysie résiduelle dans la salle de réveil même après un monitorage neuromusculaire peropératoire et un renversement de leurs effets.

Le prix d'achat des myorelaxants qui facilitent l'intubation endotrachéale (approx $2 \times \mathrm{ED}_{95}$ ) varie de $1 \$$, pour la succinylcholine, à $13 \$-16 \$$ pour l'atracurium, le vécuronium ou le mivacurium. Le coût du maintien du relâchement musculaire adéquat pendant la chirurgie ( $>90 \%$ de blocage) varie de $6 \$ / \mathrm{h}$ pour la succinylcholine à $2,25 \$$ pour le pancuronium et 8 $\$$ pour l'atracurium ou le vécuronium. Le prix des décurarisants est similaire pour les combinaisons d'atropine-néostigmine et d'atropine-édrophonium $(1,50 \$)$ ce qui est un peu plus bas que celui de la combinaison de glycopyrrolate-néostigmine $(2,50 \$)$. Toutefois, une interprétation poussée est nécessaire pour prouver l'utilité de ces données. Par exemple, comment estimer le coût du soulagement des douleurs muscu-
TABLE VIII Coût par minute de diverses activités :

\begin{tabular}{ll}
\hline & $\$$ par minute \\
\hline Anesthésiques & $0,5 \$$ \\
Salle d'opération & $10 \$$ \\
Boeing 747 en piste & $80 \$$ \\
Prix de l'anesthésie & $2 \$$ \\
\hline
\end{tabular}

laires après l'usage de succinylcholine ou la morbidité de la faiblesse prolongée en salle de réveil après avoir utilisé des myorelaxants de longue durée ? Le coût des médicaments dépend du nombre d'ampoules ouvertes et non de la quantité de médicament administrée. Des épargnes sont possibles si un nombre suffisant d'anesthésiologistes se convertissent à l'usage de myorelaxants de courte durée comme le mivacurium qui permet un départ plus hâtif de la salle de réveil mais cela ne serait envisageable qu'avec la réduction de personnel infirmier.

\section{Stratégies de compression des dépenses}

Certaines stratégies ont été utilisées pour tenter de réduire le coût de l'anesthésie. Dans la plupart, on a évalué le coût des médicaments et une variété de programmes de formation, des recommandations de pratique clinique obligatoires et les réactions à la cueillette de données sur le rendement des individus. En général, les programmes d'éducation avaient eu un succès mitigé quant au maintien d'un modèle de prescription à meilleur prix. Par exemple, Johnstone et Jozefczyk ont pu faire des beaucoup d'économies pendant la période de formation, mais en moins de deux mois, le coût des médicaments était revenu au moins à son niveau précédent. ${ }^{30}$ Selon une méthode plus imaginative mise en vigueur à l'université Duke, les recommandations de pratique pour l'utilisation des médicaments pendant l'anesthésie ont été élaborées par les médecins (Table VII). Un système de distribution de médicaments a été mis en oeuvre (c.-à-d. la disponibilité des médicaments était contrôlée), et l'adhésion aux recommandations a été notée en utilisant un registre anesthésique automatisé (Arkive $\left({ }^{8}\right){ }^{31}$ Les données sur les résultats cliniques dans la salle de réveil et les temps indicateurs du débit de patients ont été enregistrés. ${ }^{32} \mathrm{D}$ 'après ce système, le coût par personne $(66,08 \$$ US $)[24,52 \$ / \mathrm{h}]$ en 1994 a baissé à $32 \$$ $[11,46$ \$] en 1996 et, apparemment, a été maintenu à ce niveau sans détérioration mesurable de l'évolution des patients. Les tentatives antérieures de formation n'ont rapporté que peu de changement dans la façon d'utiliser les médicaments. Toutefois, ces résultats ont 
été obtenus moyennant un certain prix. Le choix des médicaments était restreint et le coût devait inclure le personnel : les médecins produisant les recommandations, l'achat du système Arkive $(60000 \$=15000 \$$ par site), la programmation informatique, la cueillette permanente de données et la distribution. Le choix de certains médicaments en vue de répondre aux recommandations consensuelles pour une "meilleure pratique» était sans aucun doute différent à mesure que les données concernant des complications périopératoires étaient rapportées. Par exemple, il aurait été difficile d'appuyer l'usage du pancuronium après la démonstration, à Copenhague, d'une augmentation considérable de complications pulmonaires postopératoires à la suite de son utilisation en comparaison avec l'atracurium ou le vécuronium. Il est possible que l'analyse des résultats à Duke dans la salle de réveil, n'ait pu quantifier ces données. Fait intéressant à noter, le coût des anesthésiques à Vancouver en 1996, sans contrôle direct, était de 40 \$ CAN! Il est important, en évaluant chaque rapport, de comparer le modèle de chirurgie et d'usage de médicament pré-tests avec les données de son propre hôpital afin de déterminer si des réductions semblables ne pourraient être faites dans un autre département. Berman et Simon ont rapporté que le coût des anesthésiques par les résidents était réduit au moyen d'un système où l'usage individuel de médicaments et leur coût sont notés et comparés à la moyenne du département. Comme on pouvait s'y attendre, l'emploi des médicaments les plus chers a diminué, mais la vérification, trois mois plus tard, a montré un rebond important du coût.

\section{Perspectipe}

Au moment où on prend conscience des coûts, il est peut-être approprié de rappeler que le prix d'achat des anesthésiques est d'environ $0,25 \%$ du budget total d'un hôpital et ne représente qu'une fraction du coût de fonctionnement d'une salle d'opération (Table VIII).

\section{Conclusion}

Avec le développement de nouveaux myorelaxants, l'anesthésiologiste a maintenant à sa disposition des médicaments qui sont presque sans effets secondaires, ont une durée d'action qui permet de bien contrôler leur activité et, dans la plupart des cas, permettent de les substituer à la succinylcholine. Les myorelaxants sont bon marché.

\section{Reférences}

(Voir page R93) 